\title{
THE TOXICITY OF JACK BEAN [Canavalia ensiformis (L.) DC.] CANATOXIN TO PLANT PATHOGENIC FUNGI
}

\author{
OLIVEIRA, A. E. A., ${ }^{1,2}$ GOMES, V. M., ${ }^{3}$ SALES, M. P., ${ }^{4}$ FERNANDES, K. V. S., ${ }^{1}$ \\ CARLINI, C. R. ${ }^{5}$ and XAVIER-FILHO, J. ${ }^{1}$ \\ ${ }^{1}$ Laboratório de Química e Função de Proteínas e Peptídeos, Centro de Biociências e Biotecnologia, Universidade \\ Estadual do Norte Fluminense, Av. Alberto Lamego, 2000, CEP 28015-620, Campos dos Goytacazes, RJ, Brazil \\ ${ }^{2}$ Departamento de Biologia, Universidade Federal do Ceará, Campus do Pici, \\ CEP 60455-760, Fortaleza, CE, Brazil \\ ${ }^{3}$ Laboratório de Fisiologia e Bioquímica de Microorganismos, Centro de Biociências e Biotecnologia, Universidade \\ Estadual do Norte Fluminense, Av. Alberto Lamego, 2000, CEP 28015-620, Campos dos Goytacazes, RJ, Brazil \\ ${ }^{4}$ Departamento de Biologia, Universidade Federal do Rio Grande do Norte, CEP 59072-970, Natal, RN, Brazil \\ ${ }^{5}$ Departamento de Biofísica, Instituto de Biociências, Universidade Federal do \\ Rio Grande do Sul, CEP 91509-900, Porto Alegre, RS, Brazil \\ Correspondence to: José Xavier-Filho, Laboratório de Química e Função de Proteínas e Peptídeos, Centro de \\ Biociências e Biotecnologia, Universidade Estadual do Norte Fluminense, Av. Alberto Lamego, 2000, \\ CEP 28015-620, Campos dos Goytacazes, RJ, Brazil, e-mail: xavier@uenf.br \\ Received March 19, 1997 - Accepted September 14, 1998 - Distributed February 23, 1999
}

(With 1 figure)

\begin{abstract}
Protein fractions obtained from seeds of the jack bean (Canavalia ensiformis) as well as the amino acid canavanine, present in these seeds, were tested for their capacity to inhibit the growth of the phytopathogenic fungi Macrophomina phaseolina, Colletotrichum gloesporioides, Sclerotium rolfsii and Fusarium oxysporum. We found that most of the proteins examined and also canavanine did not have any effect on the growth of these fungi. On the other hand the toxic protein canatoxin was found to be effective, at a concentration of $2 \%$, in the inhibition of the growth of M. phaseolina, C. gloesporioides and $S$. rolfsii.
\end{abstract}

Key words: Canavalia ensiformis, jack bean seeds, canatoxin, phytopathogenic fungi.

\section{RESUMO}

\section{Toxicidade de canatoxina de feijão-de-porco [Canavalia ensiformis (L.) DC.] a fungos fitopatogênicos}

Frações protéicas obtidas de sementes de feijão-de-porco (Canavalia ensiformis), bem como o aminoácido canavanina presente nestas sementes, foram avaliadas em sua capacidade de inibir o crescimento dos fungos fitopatogênicos Macrophomina phaseolina, Colletotrichum gloesporioides, Sclerotium rolfsii e Fusarium oxysporum. Constatamos que a maior parte das proteínas examinadas e também canavanina não apresentaram nenhum efeito sobre o crescimento desses fungos. Por outro lado, a proteína tóxica canatoxina mostrou-se efetiva, a uma concentração de $2 \%$, na inibição do crescimento de M. phaseolina, C. gloesporioides e S. rolfsii.

Palavras-chave: Canavalia ensiformis, feijão-de-porco, sementes, canatoxina, fungos fitopatogênicos.

\section{INTRODUCTION}

The jack bean (Canavalia ensiformis) is a bushy, semi-erect annual legume originated in the New World and which is grown mainly as green manure and as cover crop in soil erosion control programs.

Only occasionally its seeds are used as foodstuff due to their inherent toxicity to many forms of life (Kay, 1979; Smartt, 1990). The plant is 
known to be relatively free from attack by pests and diseases (Kay, 1979).

The jack bean has been shown to possess a multiplicity of proteins and other compounds which are considered highly toxic to several organisms including man, other mammals and invertebrates (Liener, 1969; Kay, 1979; Pusztai, 1989; Smartt, 1990; Rosenthal, 1991; Harborne, 1992; Carlini et al., 1997). We have recently shown that vicilins (7S storage proteins) from several legume seeds, including those from jack bean, inhibit spore germination of several fungi (Gomes et al., 1996). The isolation of a hitherto unknown toxic protein, canatoxin, from the jack bean meal by Carlini \& Guimarães (1981) has led to a considerable effort by these authors and their collaborators to understand its mode of action and biological significance (Carlini \& Guimarães, 1991). Recently it was found that canatoxin is highly detrimental to insects that utilize low $\mathrm{pH}$ gut conditions for protein digestion (Carlini et al., 1997).

The generally broad action of canatoxin both when intraperitoneally injected in mice and when fed to insects prompted us to verify if this protein would have any effect on the growth of phytopathogenic fungi.

\section{MATERIALS AND METHODS}

Seeds

Jack bean ( $C$. ensiformis, of landrace "Ceará") seeds were obtained from the seed bank of the Centro de Ciências Agrárias, Universidade Federal do Ceará, Fortaleza, Ceará, Brazil.

\section{Seed meal fractionation}

Seeds were separated in cotyledons and testa and the tissues were ground to fine powders. Cotyledon meal was extracted with water (1:5) for 30 min with constant stirring. The slurry was centrifuged $\left(5,900 \leftrightarrow \mathrm{g}, 4^{\circ} \mathrm{C}, 30 \mathrm{~min}\right)$ and the precipitate again resuspended in water and centrifuged at the same conditions after which it was dried by lyophilization. The supernatants were pooled, dialyzed against water, centrifuged $\left(5,900 \leftrightarrow \mathrm{g}, 4^{\circ} \mathrm{C}\right.$, $30 \mathrm{~min}$ ) for the separation of albumins (A) and globulins $(\mathrm{G})$ and both were freeze dried. The low molecular weight fraction (LMW), which passed through the dialysis membranes, was also recovered by freeze-drying.
For the preparation of fractions enriched in vicilins (7S globulins) we extracted the cotyledon meal with $0.05 \mathrm{M}$, sodium borate buffer, $\mathrm{pH}$ 8.0 , for $4 \mathrm{~h}$ at $4{ }^{\circ} \mathrm{C}$. After centrifugation $(5,900$ $\leftrightarrow \mathrm{g}, 4^{\circ} \mathrm{C}, 30 \mathrm{~min}$ ) the precipitate was discarded and the supernatant was precipitated with ammonium sulfate at $70 \%$ and the resulting supernatant again precipitated to $90 \%$ saturation. The supernatant containing vicilins was dialyzed against water and the proteins recovered by freeze drying (Sammour et al., 1984). This fraction was further run through a column of chitin $(4 \leftrightarrow 15 \mathrm{~cm})$ in $0.05 \mathrm{M}$ potassium phosphate, $\mathrm{pH}$ 7.6. Fractions were eluted with the same buffer and retained ones were desorbed by $0.1 \mathrm{~N} \mathrm{HCl}$ (Yunes et al., 1998).

Canatoxin was isolated from C. ensiformis seeds according to the method developed by Carlini \& Guimarães (1981) with modifications introduced by Barcellos (1992). Briefly, a 10\% (w:v) crude extract of $C$. ensiformis prepared in $25 \mathrm{mM}$ Tris$\mathrm{HCl}, \mathrm{pH} 7.5$ was combined with ice-cold ethanol (30\%) to form a precipitate, and the supernatant was subsequently fractionated with ammonium sulfate at $0.35-0.55$ saturation. The toxic material thus obtained was submitted to an ion-exchange chromatography step in DEAE-cellulose, equilibrated in $25 \mathrm{mM}$ Tris- $\mathrm{HCl}-100 \mathrm{mM} \mathrm{NaCl}$, $\mathrm{pH}$ 7.5. The toxin adsorbed to the resin was eluted with Tris buffer containing $200 \mathrm{mM} \mathrm{NaCl}$ and then gel-filtered in a Bio-Gel $0.5 \mathrm{~m}$ column when a pure fraction was obtained (PCNTX).

Concanavalin A (ConA) was obtained according to published methods (Moreira \& Cavada, 1984). The amino acid canavanine, present in the seeds of the jack bean, was commercially obtained from SIGMA.

\section{Fungi}

Fungi utilized were furnished by the Departamento de Fitotecnia, Centro de Ciências Agrárias, Universidade Federal do Ceará and were isolated from locally growing cultures: Macrophomina phaseolina (isolated from cowpea), Colletotrichum gloesporioides (isolated from cashew tree), Sclerotium rolfsii (isolated from cowpea) and Fusarium oxysporum (isolated from banana). The fungi were maintained on Agar Sabouraud and utilized as required.

Antifungal activity of the several C. ensiformis preparations was observed under sterile 
conditions using the disc-plate diffusion assay as described by Roberts \& Selitrenikoff (1988). Fungi (M. phaseolina, C. gloesporioides, S. rolfsii and F. oxysporum) were inoculated at the center of Petri dishes ( $8.5 \mathrm{~cm}$ diameter) containing Sabouraud Dextrose Agar $(8.5 \mathrm{ml})$. After incubation for 24$48 \mathrm{~h}$ at $25 \mathrm{rC}$ to allow for spore germination and vegetative growth, sterile filter paper discs (Whatman 3MM) were radially distributed on the agar surface, close to the expanding mycelial mat and $50 \mu \mathrm{L}$ of the protein solutions $(2 \%$ in $0.1 \mathrm{M}$ Tris-HCl buffer, $\mathrm{pH} 8.0$ ) were applied to the discs. The Petri dishes were then incubated for $24 \mathrm{~h}$ at 25 rC. A positive control employing nistatin, an antifungal compound isolated from Streptomyces noursei was run. In this manner a crescent shaped zone of inhibition of fungal growth could be observed around the paper disc if the solution being tested showed any antifungal property.

\section{Protein determination}

Protein was determined by the dye binding method of Bradford (1976) or by the absorbance at $280 \mathrm{~nm}$.

\section{DISCUSSION AND RESULTS}

The majority of the protein fractions prepared by us and the amino acid canavanine from jack bean cotyledons did not inhibit the growth of the fungi $M$. phaseolina, C. gloesporioides, $S$. rolfsii and $F$. oxysporum as seen by employing the disc- plate diffusion assay of Roberts \& Selitrenikoff (1988) (not shown). This technique measures hyphal growth and does not indicate whether there is inhibition of spore germination. Results recently reported from our laboratory show that spore germination of several phytopathogenic fungi is inhibited by vicilins (7S storage globulins) from several legume seeds including those from $C$. ensiformis (Gomes et al., 1996).

When we examined the effects of the protein canatoxin, which is toxic to mammals when intraperitoneally injected (Carlini \& Guimarães, 1991) and to hemipteran and coleopteran insects when ingested (Carlini et al., 1997), on the growth of the fungi M. phaseolina, $C$. gloesporioides, $S$. rolfsii and $F$. oxysporum we detected growth inhibition of the first three of these but not of the last one.

In Fig. 1 we show the assay plates for the growth inhibition of M. phaseolina and S. rolfsii showing that at $2 \%$ concentration canatoxin is active against these phytopathogenic fungi.

Why this protein inhibits growth of these organisms is not evident at this time. The toxic protein is apparently devoid of chitinase or chitinbinding activity (Carlini et al., 1997). The recently reported effects of canatoxin on calcium fluxes during platelet activation (Ghazaleh et al., 1997) or its interference with $\mathrm{Ca}^{2}+\mathrm{Mg}^{2}-$ ATPase of sarcoplasmic reticulum membrane vesicles (Alves et al., 1992) could likely be linked to its action on fungi cells.

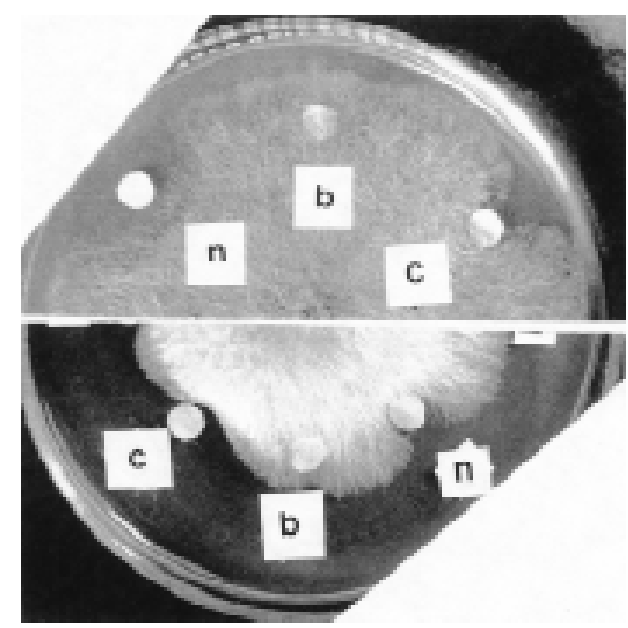

Fig. 1 - Agar plate assay for the inhibition of the growth of the phytopathogenic fungi Macrophomina phaseolina (upper panel) and Sclerotium rolfsii (lower panel). (c) pure canatoxin; (b) buffer control; (n) nistatin control. 
The understanding of the mechanisms of growth inhibition of fungi by canatoxin could be of value for our comprehension of the high toxicity power of the seeds of $C$. ensiformis.

Acknowledgements: This work was partially financed by CNPq, FINEP and PADCT. The authors are forever grateful to the deceased Grace Barcellos for her contribution to the work during its early phases.

\section{REFERENCES}

ALVES, E. W., FERREIRA-TEIXEIRA, A., FERREIRATEIXEIRA, C. \& CARLINI, C. R., 1992, Effects of canatoxin on the $\mathrm{Ca}^{2}+\mathrm{Mg}^{2}-$ ATPase of sarcoplasmic reticulum membranes. Toxicon, 30:1411-1418.

BARCELLOS, G. B. S., 1992, Canatoxin: structural analysis and comparative studies with concanavalin a in Canavalia ensiformis seeds. M.S. thesis, Universidade Federal do Rio de Janeiro.

BRADFORD, M. M., 1976, A rapid and sensitive quantitation of microgram quantities of protein dye binding. Anal. Biochem., 72: 1248-1254.

CARLINI, C. R. \& GUIMARÃES, J. A., 1981, Isolation and characterization of a toxic protein from Canavalia ensiformis (jack bean) seeds, distinct from concanavalin A. Toxicon, 19: 667-676.

CARLINI, C. R. \& GUIMARÃES, J. A., 1991, Plant and microbial toxins as hemilectins: emphasis on canatoxin. Toxicon, 29: 791-806.

CARLini, C. R., OLIVEIRA, A. E. A., AZAMBUJA, P., XAVIER-FILHO, J. \& WELLS, M. A., 1997, Biological effects of canatoxin in different insect models: evidence for a proteolytic activation of the toxin by insect cathepsin-like enzymes. J. Econ. Entomol., 90: 340-348.

GHAZALEH, F. A., FRANCISCHETTI, I. M. B., GOMBAROVITS, M. E. C. \& CARLINI, C. R., 1997, Stimulation of calcium influx and platelet activation by canatoxin: methoxy-verapamil inhibition and downregulation by cGMP. Arch. Biochem. Biophys., 339: 362-367.
GOMES, V. M., SALES, M. P., FERNANDES, K. V. S., CORDEIRO, R. A. \& XAVIER-FILHO, J., 1996, The effects of vicilin storage proteins from cowpea seeds on the development of phytopathogenic fungi. XXV Meeting of the Brazilian Society of Biochemsitry and Molecular Biology, Caxambu. Abstracts Book, p. 34 (E-32).

HARBORNE, J. B., 1992, Introduction to Ecological Biochemistry. Academic Press, London, 318p.

KAY, D. E., 1979, Crop and Product Digest № 3 - Food Legumes. Tropical Products Institute, London, p. 435.

LIENER, I., 1969, Toxic constituents of plant foodstuffs. Academic Press, New York.

MOREIRA, R. A. \& CAVADA, B. S., 1984, Lectin from Canavalia brasiliensis Mart. Isolation, characterization and behaviour during germination. Biol. Plant., 26: 113120.

PUSZTAI, A., 1989, Lectins. In: P. R. Cheeke (ed.), Toxicants of Plant Origin., Vol. III, Proteins and Amino Acids. CRC Press, Inc., Boca Raton, FL, pp. 29-71.

ROBERTS, W. K.\& SELITRENIKOFF, C. P., 1988, Plant cell and bacterial chitinase differ in antifungal activity. $J$. Gen. Microbiol., 134: 169-176.

ROSENTHAL, G. A., 1991, The Biochemical Basis for the Deleterious Effects of L-canavanine. Phytochemistry, 30: 1055-1058.

SAMMOUR, R. H., GATEHOUSE, J. A., GILROY, J. \& BOULTER, D., 1984, The homology of the major storage protein of jack bean (Canavalia ensiformis) to pea vicilin and its separation from $\alpha$-manosidase. Planta, 161: 61-70.

SMARTT, J., 1990, Grain legumes. Evolution and genetic resources. Cambridge University Press, Cambridge, 379p.

YUNES, A. N. A., ANDRADE, M. T., SALES, M. P., MORAIS, R. A., FERNANDES, K. V. S., GOMES, V. M. \& XAVIER-FILHO, J., 1998, Legume seed vicilins (7S storage proteins) interfere with the development of the cowpea weevil [Callosobruchus maculatus (F.)]. J. Sci. Food Agric., 76: 111-116. 